\title{
How $\mathrm{pH}$ is regulated during amelogenesis in dental fluorosis (Review)
}

\author{
MEI JI, LILI XIAO, LE XU, SHENGYUN HUANG and DONGSHENG ZHANG \\ Department of Stomatology, Shandong Provincial Hospital Affiliated to Shandong University, \\ Jinan, Shandong 250021, P.R. China
}

Received August 18, 2017; Accepted December 1, 2017

DOI: $10.3892 /$ etm.2018.6728

\begin{abstract}
Amelogenesis is a complicated process that concerns the interaction between growing hydroxyapatite crystals and extracellular proteins, which requires the tight regulation of $\mathrm{pH}$. In dental fluorosis, the balance of $\mathrm{pH}$ regulation is broken, leading to abnormal mineralization. The current review focuses on the electrolyte transport processes associated with $\mathrm{pH}$ homeostasis, particularly regarding the changes in ion transporters that occur during amelogenesis, following exposure to excessive fluoride. Furthermore, the possible mechanism of fluorosis is discussed on the basis of acid hypothesis. There are two main methods by which $\mathrm{F}^{-}$accelerates crystal formation in ameloblasts. Firstly, it induces the release of protons, lowering the $\mathrm{pH}$ of the cell microenvironment. The decreased $\mathrm{pH}$ stimulates the upregulation of ion transporters, which attenuates further declines in the $\mathrm{pH}$. Secondly, $\mathrm{F}^{-}$triggers an unknown signaling pathway, causing changes in the transcription of ion transporters and upregulating the expression of bicarbonate transporters. This results in the release of a large amount of bicarbonate from ameloblasts, which may neutralize the $\mathrm{pH}$ to form a microenvironment that favors crystal nucleation. The decreased $\mathrm{pH}$ stimulates the diffusion of $\mathrm{F}^{-}$into the cytoplasm of amelobalsts along the concentration gradient formed by the release of protons. The retention of $\mathrm{F}^{-}$causes a series of pathological changes, including oxidative and endoplasmic reticulum stress. If the buffering capacity of ameloblasts facing $\mathrm{F}^{-}$toxicity holds, normal mineralization occurs; however, if $\mathrm{F}^{-}$levels are high enough to overwhelm the buffering capacity of ameloblasts, abnormal mineralization occurs, leading to dental fluorosis.
\end{abstract}

Correspondence to: Professor Dongsheng Zhang, Department of Stomatology, Shandong Provincial Hospital Affiliated to Shandong University, 324 Jingwu Road, Jinan, Shandong 250021, P.R. China E-mail: ds63zhang@sdu.edu.cn

Key words: dental fluorosis, $\mathrm{pH}$ regulation, electrolyte transport, amelogenesis, ameloblast, ion transporters

\section{Contents}

1. Introduction

2. Mechanism of dental fluorosis

3. Amelogenesis and the regulation of $\mathrm{pH}$

4. Electrolyte transport processes involved in $\mathrm{pH}$ regulation during amelogenesis

5. The effect of fluoride on $\mathrm{pH}$ regulation during amelogenesis

6. Conclusions

\section{Introduction}

Dental fluorosis is an enamel defect caused by the excessive intake of fluoride during enamel formation. In deciduous teeth, it occurs during the embryonic phase, while in permanent teeth, it occurs primarily in children aged 2-8 years old (1-4). The primary sources of fluoride intake are from food and water, as well as from toothpaste, which contains added fluoride. Fluoride is also being added to different materials, including fluoride varnish, fluoride foam and dental resin to prevent the occurrence of dental caries. All these methods increase the morbidity of dental fluorosis (1). The incidence of dental fluorosis is currently a problem worldwide, although the prevalence of dental fluorosis varies in different countries. In the USA, $\sim 25 \%$ of the population have dental fluorosis and its incidence is also high in China, $\sim 11.7 \%$ of adolescents of 12 years old suffer dental fluorosis $(2,4)$. According to the Dean's index, dental fluorosis may be classified into five types: Questionable, very mild, mild, moderate and severe (5). In clinical practice, dental fluorosis may be classified into three types: Chalk, discoloration and defective (6).

Enamel formation by ameloblasts is a complex process. The primary elements of enamel hydroxyapatite are present in the crystalline form $(7,8)$. It has been demonstrated that $8-14 \mathrm{H}^{+}$ are released in the extracellular environment as the minimum repeating structure of hydroxyapatite crystals are formed, thus lowering the $\mathrm{pH}$ (7-9). To maintain the $\mathrm{pH}$ balance, ameloblasts must buffer the protons. During the secretory stage, amelogenins may serve an important role in buffering the $\mathrm{pH}(9,10)$; however, during the maturation stage, ameloblasts secrete bicarbonate into the enamel matrix to neutralize the microenvironment (7,9-11). The process of enamel formation requires strict control of extracellular $\mathrm{pH}(7-9,11)$; hydroxyapatite crystal growth and proteinase activity in the extracellular 
space are $\mathrm{pH}$-dependent phenomena $(7,8,12)$. $\mathrm{pH}$ therefore serves an important role during amelogenesis, which is the basis of enamel formation.

The current review discusses the regulation of $\mathrm{pH}$ during amelogenesis in dental fluorosis and also explores the effects of changes in ion transporters on dental fluorosis. This may identify future directions of research to identify potential novel treatments of dental fluorosis.

\section{Mechanism of dental fluorosis}

There are multiple potential causes of dental fluorosis; however, the precise mechanism by which dental fluorosis occurs remain controversial (13-15). Current investigations into these mechanisms primarily focus on the direct effects on the ameloblasts and the indirect effects on the forming matrix (16). Fluoride has three distinct effects on ameloblasts. Firstly, it has two contrasting effects on cell proliferation. Micromolar $\mathrm{F}^{-}$promotes the proliferation of ameloblasts, while millimolar $\mathrm{F}^{-}$inhibits their proliferation, suggesting that higher levels of fluoride may inhibit the proliferation of ameloblasts $(17,18)$. Secondly, the differentiation of ameloblasts may be regulated by $\mathrm{F}^{-}$via the mitogen-activated protein kinase pathway (19). Thirdly, the apoptosis of ameloblasts increases during oxidative stress if $\mathrm{F}^{-}$levels are high (20). Yang et al (21) demonstrated that high levels of fluoride induce the apoptosis of ameloblasts by downregulating Bcl-2. In terms of indirect fluoride-associated effects, fluoride may interfere with the synthesis, secretion and intracellular transportation of enamel matrix proteins in ameloblasts $(18,22)$. The retention of matrix proteins is not only the result of the decreased activity of proteases, including matrix metalloproteinase-20 (MMP-20) (23) and Kallikrein 4 (KLK4) (24), but is also the result of more effective binding to fluoridated apatite $(1,13)$. Furthermore, high levels of fluoride may induce changes the structure and function of amelogenin, which serves an important role in buffering $\mathrm{pH}$, thereby contributing to the disruption of $\mathrm{pH}$ regulation (25). $\mathrm{pH}$ is important in the mechanisms mentioned above and $\mathrm{pH}$ may directly or indirectly regulatet these mechanisms. Duan et al (26) identified that residual protein (emdogain) exists in the enamel of patients with cystic fibrosis and dental fluorosis. This was determined to be a consequence of disordered $\mathrm{pH}$ levels, which lead to abnormal proteolytic activity and defective endocytosis. Thus, $\mathrm{pH}$ serves an important role during the entire process of amelogenesis. It is therefore important to determine how $\mathrm{pH}$ is regulated during amelogenesis when intake of fluoride remains high for a prolonged period of time.

\section{Amelogenesis and the regulation of $\mathrm{pH}$}

There are five stages of amelogenesis, which include: The pre-ameloblast stage, the pre-secretory stage, the secretory stage, the transition stage and the maturation stage $(25,27)$. Of these five stages, two are the most important: The secretory and the maturation stages $(4,28)$. During the secretory stage, ameloblasts secrete a number of proteins, including amelogenin, ameloblastin, enamelin and MMP20 $(29,30)$. These proteins organize the nascent structure of ameloblasts, which are composed of long thin crystal ribbons (29). During the secretory stage, ameloblasts construct the full length of the enamel ribbons; however, this matrix remains only partly mineralized until the maturation stage $(29,31,32)$. During this stage, the extracellular $\mathrm{pH}$ is $\sim 7.23(9,29,33)$. During the maturation stage, matrix proteins are degraded by a stage-specific protease and crystals develop into their final hardened forms $(4,7,28)$. This stage-specific protease is KLK4, which can degrade matrix proteins and facilitate their resorption $(4,34)$. In addition, high numbers of calcium and phosphate ions are secreted into the enamel matrix (30). This allows enamel ribbons to widen, leading to increased hydrogen release $(7,29)$. During the efflux of calcium and phosphate ions, hydroxyapatite (HA) may be deposited. At the same time with HA deposition, hydrogen ions are released, lowering the $\mathrm{pH}$ of the enamel matrix (33). Depending on the phosphate precursor, the precipitation of HA releases 8-14 moles of hydrogen ions per mole of HA, which acidifies the enamel matrix $(4,10,29,35)$. At this stage, extracellular pH may decrease to $<6.0(9,29,33)$.

However, $\mathrm{pH}$ levels may vary during the maturation stage. Due to cyclic oscillations of ameloblasts between the smooth-ended (SE) and ruffle-ended (RE) forms, the $\mathrm{pH}$ in the enamel matrix periodically fluctuates between neutral $(\mathrm{pH} 7.2)$ and acidic (pH 5.8) $(7,11,30,36)$.

To ensure that $\mathrm{pH}$ levels change as required during the different stages, an effective $\mathrm{pH}$ regulation mechanism is required. The primary extracellular buffering mechanism used by ameloblasts is the bicarbonate buffer system (7,9-11), particularly during the maturation stage $(9,37)$. During amelogenesis, ameloblasts secrete bicarbonate into the enamel matrix to buffer the protons produced by the growth of hydroxyapatite crystals. During the maturation of enamel, carbonic anhydrase type VI, which is a secreted type of carbonic anhydrase, may catalyze the formation of $\mathrm{CO}_{2}$ and $\mathrm{H}_{2} \mathrm{O}$ from carbonic acid, formed by bicarbonate buffering of the protons in the enamel space $(9,38)$. Furthermore, Sasaki et al (11) suggested that an acidic $\mathrm{pH}$ in $\mathrm{RE}$ ameloblasts may be due to the release of protons, which may contribute to $\mathrm{pH}$ regulation. Due to the transportation of protons and bicarbonate, the balance between the intra- and extracellular $\mathrm{pH}$ of ameloblasts may be maintained.

\section{Electrolyte transport processes involved in $\mathrm{pH}$ regulation during amelogenesis}

The transport of ions in and out of cells occurs in two ways, active transport and passive diffusion, and this is also the case in ameloblasts. Ion transporters participate in this process. Ions associated with amelogenesis predominantly include calcium, phosphonium, chloridion, protons and bicarbonate, and primarily rely on ion transporters to enter and leave ameloblasts. Previous studies have demonstrated that there are many ion transporters on the membrane of ameloblasts, including $\mathrm{Ca}_{\gamma} 1$, inwardly rectifying potassium channel $\left(\mathrm{K}_{\mathrm{ir}} 1.1\right)$, epithelial sodium channel, anion exchange protein (AE)1, AE2, electrogenic sodium biocarbonate cotransporter (NBC)1, NBCe1, sodium-calcium exchanger 1-3, sodium-hydrogen antiporter 1 (NHE-1), sodium/potassium/calcium exchanger 4, $\mathrm{H}^{+}$-adenosine triphosphate (ATP)ase, cystic fibrosis transmembrane conductance regulator (CFTR), $\mathrm{H} / \mathrm{Cl}$ exchange transporter (ClC)-3, ClC-5, ClC-7, gap junction $\alpha-1$ protein 
(Cx43) and PAT-1 (16,30,36,39-51). Among these ion transporters, some are responsible for regulating $\mathrm{pH}$ and include ClC-5, ClC-7, CFTR, NHE-1, NBCe1, AE1, AE2 and pendrin. As aforementioned, the formation of hydroxyapatite during the maturation stage of amelogenesis generates a large quantity of protons; to sustain the growth of crystals, these protons must be neutralized $(7,42,52)$, potentially via the secretion of neutralizing ions, such as bicarbonate (30).

CFTR serves an important role in transporting bicarbonate into the enamel space to buffer protons in ameloblasts and locates on the apical plasma membrane during the maturation stage of ameloblasts (52). Paine et al (8) demonstrated that bicarbonate was transported by apical AE2a, basolateral NBCel and apical CFTR. Furthermore, previous studies have identified that CFTR is a critical factor in the regulation of $\mathrm{pH}$ during the maturation of ameloblasts and is essential for enamel mineralization (52-54). Duan et al (26) demonstrated that CFTR inhibition and treatment with CFTR siRNA may increase intracellular $\mathrm{pH}$. Sui et al (53) placed incisors taken from mice with the cystic fibrosis gene knocked out in $\mathrm{pH}$ indicator solution and indicated that they were acidic. CFTR is a classical $\mathrm{Cl}^{-}$channel and transports bicarbonate in two main ways, accompanied by the transportation of chloride. CFTR stimulates the transport activity of Slc26a members, leading to bicarbonate efflux (54-56). Additionally, CFTR is permeable to bicarbonate $(54,57,58)$. Although the results of previous studies have indicated that CFTR is more permeable to $\mathrm{Cl}^{-}$than to bicarbonate, studies have revealed that CFTR may be responsible for $>50 \%$ of the total bicarbonate efflux in pancreatic duct cells $(54,57)$.

Solute carrier (SLC) 4 bicarbonate transporters serve an important role in the transport of bicarbonate and the regulation of $\mathrm{pH}$ in different types of cells $(8,59)$. SLC4A2 codes for AE2, an anion-exchanger; whereas SLC4A4 codes for NBCe1, a bidirectionally electrogenic transmembrane ion-transporter (60). Depending on different cell types, NBCe1 is able to co-transport two or three bicarbonate ions per $\mathrm{Na}^{+}$ion (60). However, the location of AE2 and NBCe1 remains controversial. Paine et al (8) and Lacruz et al (43) indicated that NBCe1 is located on the basolateral membrane and AE2 is located on the apical plasma membrane. However, Bronckers et al (61) demonstrated that AE2 is located on the basolateral membrane and that NBCel is located in the papillary layer cells of the enamel organ. The difference between these studies may be due to the different methods employed and the different age groups of the animals in each of the studies (49). Overall, it is considered that, following basolateral bicarbonate uptake by NBCe1 and AE2, apical bicarbonate secretion is mediated by CFTR (62). Gawenis et al (63) demonstrated that mice lacking AE2 were edentulous (63). Additionally, patients harboring NBCe1 mutations exhibit different levels of enamel abnormalities $(64,65)$. These results all confirm the important role of AE2 and NBCe1 in the transport of bicarbonate in ameloblasts and in regulating $\mathrm{pH}$ levels (8).

Pendrin is another member of SLC family, which is encoded by SLC26A4 located on the apical membrane of ameloblasts (45). It is able to transport chloride, bicarbonate, iodine and formate (45). A number of studies have demonstrated that it is able to regulate luminal $\mathrm{pH}$ in the kidney, inner ear and thyroid (66-68). However, the transport of bicarbonate by pendrin is not critical for enamel formation. Bronckers et al (45) identified that ameloblasts may achieve the normal mineralization of enamel in pendrin knockout rodents.

ClC-5 and $\mathrm{ClC}-7$ are voltage-gated chloride channels, which are responsible for transporting $\mathrm{Cl}^{-}$and $\mathrm{H}^{+}$. Previous studies have generally focused on the regulation of dentin development by ClC-5 $(41,69)$. Duan et al $(70)$ demonstrated that $\mathrm{ClC}-5$ is also expressed by ameloblasts of tooth germ. The enamel of ClC-5 knockout mice is easily detached from dentin and this may affect enamel formation (41,70). ClC-7 is a $\mathrm{Cl}^{-} / \mathrm{H}^{+}$antiporter $(71,72)$. It has been proven that, during the maturation stage of ameloblasts, the highest levels of ClC-7 are immunolocated in ameloblast vesicles $(48,71,72)$. Osteopetrosis-associated transmembrane protein 1, which centralizes to the lysosomes of all cells and lies on the ruffled border membrane of osteoclasts, is essential for the transport activity of ClC-7 (71-74). In osteoclasts, Kornak et al (74) demonstrated thatClC-7 was importantfor the acidification of the resorption lacuna; however, this was not the case in lysosomes. The lysosomal $\mathrm{pH}$ and degree of enamel mineralization did not change following ClC-7 knockout $(71,75,76)$. However, ClC-7 may serve an important role during tooth eruption, as it has been determined that $\mathrm{ClC}-7$ knockout mice experience a failure of tooth eruption $(71,74,75,77)$; however, further studies are required to explore the exact mechanism of action. Thus, unlike its function in osteoclasts, $\mathrm{ClC}-7$ is not critical for ameloblast function (71).

NHE1 is a $\mathrm{Na}+/ \mathrm{H}^{+}$exchanger located on basolateral membrane of ameloblasts and is strongly immunoactivated in the secretory and maturation stages of amelogenesis (42). It co-operates with other transporters to transport $\mathrm{H}^{+}$to the enamel matrix, thus altering $\mathrm{pH}$. Carbonic anhydrase (CA) is a zinc metalloenzyme required for the survival of pro- and eukaryotic cells $(38,78)$. It is able to catalyze the reaction of carbon dioxide and water to produce carbonic acid, which then rapidly dissociates into hydrogen and bicarbonate ions $(38,78,79)$. Among $>12 \mathrm{CA}$ genes, it has been proven that CA II and CA VI are expressed in maturation ameloblasts $(38,78,79)$. CA II is the most abundantly expressed isozyme in all major mammalian organs and is localized in the cytoplasm. It can pump $\mathrm{H}^{+}$into the enamel with the aid of $\mathrm{H}^{+}$-ATPase type V (80). CA VI is a secreted enzyme located in the enamel, which buffers local $\mathrm{pH}$ by providing bicarbonate ions or recycling excess carbonic acid $(38,78)$. Generally speaking, CA II and CA VI participate in the $\mathrm{pH}$ homeostasis of ameloblasts by transporting $\mathrm{H}^{+}$and $\mathrm{HCO}_{3}^{-}$.

\section{The effect of fluoride on $\mathrm{pH}$ regulation during amelogenesis}

Excessive fluoride may cause $\mathrm{pH}$ disturbance during amelogenesis. As the $\mathrm{pH}$ balance is primarily maintained by electrolyte transporters, fluoride may serve a role during electrolyte transportation. Zheng et al (25) demonstrated that fluoride may indirectly regulate ameloblasts in mice and humans. The upregulation of NBCe1 during ameloblast maturation is not directly stimulated by fluoride, as NBCe1 expression is unaffected following the addition of fluoride. The exact mechanism of action of NBCe1 upregulation may 


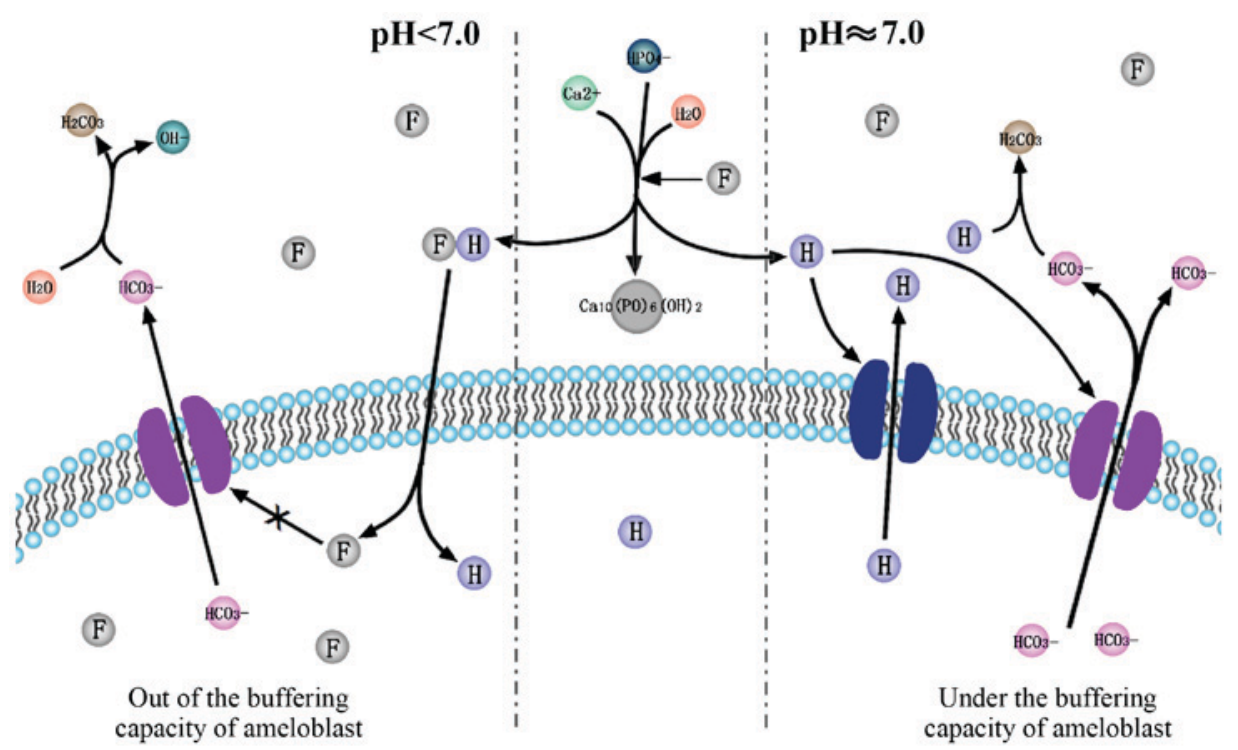

Figure 1. Schematic representation of the association between $\mathrm{F}^{-}$and $\mathrm{pH}$ regulation during amelogenesis. $\mathrm{F}^{-}$accelerates crystal formation and produces a large number of protons, which may lower the $\mathrm{pH}$ of the microenvironment. The decrease in $\mathrm{pH}$ upregulates the expression of ion transporters in ameloblasts in two ways: Directly and indirectly, via a currently unknown signaling pathway. These two processes lead to the excessive release of $\mathrm{HCO}_{3}{ }^{-}$, which may neutralize the $\mathrm{pH}$ to form a microenvironment favoring crystal nucleation. However, when the decrease in $\mathrm{pH}$ levels is severe, more $\mathrm{F}^{-}$diffuses into cytoplasm of amelobalsts along the concentration gradient formed by the release of protons, overwhelming the buffering capacity of ameloblasts. The retention of $\mathrm{F}^{-}$induces a series of pathological changes, including the dysregulation of ion transportation. The decrease in pH levels cannot be neutralized, which causes the abnormality of crystal formation, leading to dental fluorosis.

be due to mineral deposition and matrix acidification (25). Paine et al (8) demonstrated that AE2 and NBCe1 expression is upregulated when $\mathrm{pH}$ levels are low. A previous study investigating the association between microRNA (miRNA) 224 expression and acidification indicated that acidification caused by fluoride may downregulate miRNA 224 expression (81). Furthermore, miRNA 224 expression was inversely correlated with the expression of SLC4A4 and CFTR (81). Further studies are required to investigate the direct effect of fluoride on their expression.

The effect of fluoride on $\mathrm{pH}$ regulation has been verified. A number of in vitro and in vivo studies have proven that $\mathrm{F}^{-}$is able to accelerate crystal formation and induce hypermineralized lines in secretory enamel $(6,61,82)$. The process of crystal growth produces a large number of protons, which can acidify the microenvironment. A decreased $\mathrm{pH}$ may induce a series of changes in electrolyte transporters and may also affect the toxicity of $\mathrm{F}^{-}(4,8,25,29)$. $\mathrm{F}^{-}$cannot enter the ameloblast directly and must be converted to hydrogen fluoride (HF) beforehand (4). A low extracellular $\mathrm{pH}$ promotes this conversion; $>25$ times $\mathrm{HF}$ is formed at $\mathrm{pH} 6.0$ compared with at $\mathrm{pH} 7.4$, as determined by the Henderson-Hasselbalch equation $(4,29)$. Due to the concentration gradient of $\mathrm{pH}, \mathrm{HF}$ can diffuse easily into the cytoplasm from the enamel matrix and revert to $\mathrm{F}^{-}$in the neutral cytoplasm; it cannot consequently easily diffuse out of the cell $(4,29,83,84)$. Increased $\mathrm{F}^{-}$concentration in the cytoplasm can induce oxidative stress by reducing the activity of antioxidant enzymes, which affects a variety of structures and processes of normal cells due to reactive oxygen species accumulation (4,85-87). Furthermore, fluoride ions in the cytoplasm may induce endoplasmic reticulum (ER) stress, including the phosphorylation of eukaryotic initiation factor 2 , which may result in a decrease of overall protein production, including secretion of the protease KLK4 $(4,29,88,89)$. Thus,
$\mathrm{F}^{-}$induces more severe toxicity in ameloblasts undergoing maturation (90-92).

Based on the acidic hypothesis of $\mathrm{F}^{-}$and the $\mathrm{pH}$ regulation in amelogenesis, the current review hypothesizes that $\mathrm{F}^{-}$is associated with $\mathrm{pH}$ regulation during amelogenesis. $\mathrm{F}^{-}$accelerates crystal formation in ameloblasts in two different ways (Fig. 1). Firstly, it stimulates the release of protons and lowers the $\mathrm{pH}$ of the cell microenvironment. This upregulates the expression of ion transporters, which transport $\mathrm{H}^{+}$and $\mathrm{HCO}_{3}^{-}$. Yet through this complicated regulation of $\mathrm{H}^{+}$and $\mathrm{HCO}_{3}^{-}$in and out of ameloblasts by different ion transporters mentioned above, the net efflux of $\mathrm{HCO}_{3}{ }^{-}$exceeds $\mathrm{H}^{+}$. Secondly, it triggers unknown signaling pathways and upregulates bicarbonate transporters, including NBCe1, AE2, CA2, CA6, CFTR. Upregulated bicarbonate transporters release a large amount of bicarbonate from the ameloblasts, which may neutralize the $\mathrm{pH}$ to form a microenvironment that favors crystal nucleation. By contrast, following a decrease in the $\mathrm{pH}$, more $\mathrm{F}^{-}$diffuses into cytoplasm of amelobalsts along the concentration gradient formed by the release of protons. The retention of $\mathrm{F}^{-}$induces a series of pathological changes, including oxidative and ER stress. Under the buffering capacity of ameloblasts facing $\mathrm{F}^{-}$toxicity, normal mineralization occurs; however, if the buffering capacity of ameloblasts is overwhelmed by excessive $\mathrm{F}^{-}$, hypomineralization occurs, which may cause dental fluorosis. Further studies are required to investigate the signaling pathways involved and the exact process by which ions are transported.

\section{Conclusions}

Amelogenesis is a complicated process that involves crystal formation, the removal of matrix proteins and ions transportation. The $\mathrm{pH}$ of the enamel matrix fluctuates during different stages of ameloblast development. Under normal conditions, $\mathrm{pH}$ 
levels are regulated and ameloblasts may perform their normal function and stimulate normal mineralization. CFTR, AE2, NBCe1, ClC-5, ClC-7, NHE1, CA2, CA6 and $\mathrm{H}^{+}$-ATPase type V are all involved in the regulation of $\mathrm{pH}$. However, under high fluoride concentrations, $\mathrm{pH}$ regulation becomes dysregulated. This causes the malfunction of ameloblasts, resulting in hypomineralization and dental fluorosis. The effect of fluoride on ameloblasts is due to its impact on electrolyte transporters and its direct diffusion into the cytoplasm in an acidic environment.

\section{Acknowledgements}

Not applicable.

\section{Funding}

The current review was supported by the Natural Science Foundation of Shandong Province, China (grant no. ZR2014HQ067).

\section{Availability of data and materials}

Not applicable.

\section{Authors' contributions}

This review is the result of joint efforts. DZ designed the study, MJ was responsible for writing the manuscript, $\mathrm{LXu}$ constructed the figure, LXia analyzed and summarized the literature. SH helped with analysis of the literature, assisted in providing constructive discussions and revised the manuscript. All authors read and approve the final manuscript.

\section{Ethics approval and consent to participate}

Not applicable.

\section{Patient consent for publication}

Not applicable.

\section{Competing interests}

The authors declare that they have no competing interests.

\section{References}

1. Aoba T and Fejerskov O: Dental fluorosis: Chemistry and biology. Crit Rev Oral Biol Med 13: 155-170, 2002.

2. Beltrán-Aguilar ED, Barker L and Dye BA: Prevalence and severity of dental fluorosis in the United States, 1999-2004. NCHS Data Brief: 1-8, 2010.

3. Denbesten P and Li W: Chronic fluoride toxicity: Dental fluorosis. Monogr Oral Sci 22: 81-96, 2011.

4. Sierant ML and Bartlett JD: Stress response pathways in ameloblasts: Implications for amelogenesis and dental fluorosis. Cells 1: 631-645, 2012.

5. Mohamed AR, Thomson WM and Mackay TD: An epidemiological comparison of Dean's index and the developmental defects of enamel (DDE) index. J Public Health Dent 70: 344-347, 2010.

6. Lyaruu DM, Medina JF, Sarvide S, Bervoets TJ, Everts V, Denbesten PK, Smith CE and Bronckers AL: Barrier formation: Potential molecular mechanism of enamel fluorosis. J Dent Res 93: 94-102, 2014.
7. Smith CE: Cellular and chemical events during enamel maturation. Crit Rev Oral Biol Med 9: 128-161, 1998.

8. Paine ML, Snead ML, Wang HJ, Abuladze N, Pushkin A, Liu W Kao LY, Wall SM, Kim YH and Kurtz I: Role of NBCe1 and AE2 in secretory ameloblasts. J Dent Res 87: 391-395, 2008.

9. Lacruz RS, Nanci A, Kurtz I, Wright JT and Paine ML: Regulation of pH during amelogenesis. Calcif Tissue Int 86: 91-103, 2010.

10. Simmer JP and Fincham AG: Molecular mechanisms of dental enamel formation. Crit Rev Oral Biol Med 6: 84-108, 1995.

11. Sasaki S, Takagi $\mathrm{T}$ and Suzuki M: Cyclical changes in $\mathrm{pH}$ in bovine developing enamel as sequential bands. Arch Oral Biol 36: 227-231, 1991.

12. Takagi T, Ogasawara T, Tagami J, Akao M, Kuboki Y, Nagai N and LeGeros RZ: pH and carbonate levels in developing enamel. Connect Tissue Res 38: 181-205, 1998.

13. Bawden JW, Crenshaw MA, Wright JT and LeGeros RZ: Consideration of possible biologic mechanisms of fluorosis. J Dent Res 74: 1349-1352, 1995.

14. Robinson C,Connell S and Kirkham J: Dental enamel-a biological ceramic: Regular substructures in enamel hydroxyapatite crystals revealed by atomic force microscopy. J Mater Chem 14: 2242-2248, 2004.

15. Robinson C, Connell S, Kirkham J, Brookes SJ, Shore RC and Smith AM: The effect of fluoride on the developing tooth. Caries Res 38: 268-276, 2004.

16. Bronckers AL, Lyaruu DM and DenBesten PK: The impact of fluoride on ameloblasts and the mechanisms of enamel fluorosis. Crit Rev Oral Biol Med 88: 877-893, 2009.

17. Yan Q, Zhang Y, Li W and Denbesten PK: Micromolar fluoride alters ameloblast lineage cells in vitro. J Dent Res 86: 336-340, 2007.

18. Wei W, Gao Y, Wang C, Zhao L and Sun D: Excessive fluoride induces endoplasmic reticulum stress and interferes enamel proteinases secretion. Environ Toxicol 28: 332-341, 2013.

19. Zhang Y, Li W, Chi HS, Chen J and Denbesten PK: JNK/c-Jun signaling pathway mediates the fluoride-induced down-regulation of MMP-20 in vitro. Matrix Biol 26: 633-641, 2007.

20. Jacinto-Alemán LF, Hernández-Guerrero JC, Trejo-Solís C, Jiménez-Farfán MD and Fernández-Presas AM: In vitro effect of sodium fluoride on antioxidative enzymes and apoptosis during murine odontogenesis. J Oral Pathol Med 39: 709-714, 2010.

21. Yang T, Zhang Y, Li Y, Hao Y, Zhou M, Dong N and Duan X: High amounts of fluoride induce apoptosis/cell death in matured ameloblast-like LS8 cells by downregulating Bcl-2. Arch Oral Biol 58: 1165-1173, 2013.

22. Matsuo S, Inai T, Kurisu K, Kiyomiya K and Kurebe M: Influence of fluoride on secretory pathway of the secretory ameloblast in rat incisor tooth germs exposed to sodium fluoride. Arch Toxicol 70: 420-429, 1996.

23. Hannas AR, Pereira JC, Granjeiro JM and Tjäderhane L: The role of matrix metalloproteinases in the oral environment. Acta Odontol Scand 65: 1-13, 2007.

24. Denbesten PK and Heffernan LM: Enamel proteases in secretory and maturation enamel of rats ingesting 0 and 100 PPM fluoride in drinking water. Adv Dent Res 3: 199-202, 1989.

25. Zheng L, Zhang Y, He P, Kim J, Schneider R, Bronckers AL, Lyaruu DM and DenBesten PK: NBCel in mouse and human ameloblasts may be indirectly regulated by fluoride. J Dent Res 90: 782-787, 2011.

26. Duan X, Mao Y, Wen X, Yang T and Xue Y: Excess fluoride interferes with chloride-channel-dependent endocytosis in ameloblasts. J Dent Res 90: 175-180, 2011.

27. Nanci A: Ten Cate's oral histology: Development, structure, and function. Ebook, MosbyElsevier, pp. 1-432, 2007.

28. Hu JC, Chun YH, Al Hazzazzi T and Simmer JP: Enamel formation and amelogenesis imperfecta. Cells Tissues Organs 186: 78-85, 2007.

29. Sharma R, Tsuchiya M, Skobe Z, Tannous BA and Bartlett JD: The acid test of fluoride: How $\mathrm{pH}$ modulates toxicity. PLoS One 5: e10895, 2010.

30. Varga G, Kerémi B, Bori E and Földes A: Function and repair of dental enamel-potential role of epithelial transport processes of ameloblasts. Pancreatology 15 (Suppl 4): S55-S60, 2015.

31. Nanci A and Smith CE: Development and calcification of enamel. Calcification in biological systems, pp. 313-343, 1992.

32. Bartlett JD and Simmer JP: Proteinases in developing dental enamel. Crit Rev Oral Biol Med 10: 425-441, 1999.

33. Smith CE, Issid M, Margolis HC and Moreno EC: Developmental changes in the $\mathrm{pH}$ of enamel fluid and its effects on matrix-resident proteinases. Adv Dent Res 10: 159-169, 1996. 
34. Simmer JP, Fukae M, Tanabe T, Yamakoshi Y, Uchida T, Xue J, Margolis HC, Shimizu M, DeHart BC, Hu CC and Bartlett JD: Purification, characterization, and cloning of enamel matrix serine proteinase 1. J Dent Res 77: 377-386, 1998.

35. Smith CE, Chong DL, Bartlett JD and Margolis HC: Mineral acquisition rates in developing enamel on maxillary and mandibular incisors of rats and mice: Implications to extracellular acid loading as apatite crystals mature. J Bone Miner Res 20: 240-249, 2005

36. Damkier HH, Josephsen K, Takano Y, Zahn D, Fejerskov O and Frische S: Fluctuations in surface $\mathrm{pH}$ of maturing rat incisor enamel are a result of cycles of $\mathrm{H}(+)$-secretion by ameloblasts and variations in enamel buffer characteristics. Bone 60: 227-234, 2014.

37. Bronckers AL, Lyaruu DM, Guo J, Bijvelds MJ, Bervoets TJ, Zandieh-Doulabi B, Medina JF, Li Z, Zhang Y and DenBesten PK: Composition of mineralizing incisor enamel in CFTR-deficient mice. Eur J Oral Sci 123: 9-16, 2015.

38. Smith CE, Nanci A and Moffat P: Evidence by signal peptide trap technology for the expression of carbonic anhydrase 6 in rat incisor enamel organs. Eur J Oral Sci 114 (Suppl 1): S147-S153 Discussion 164-165, 380-381, 2006.

39. Hou J, Situ Z and Duan X: ClC chloride channels in tooth germ and odontoblast-like MDPC-23 cells. Arch Oral Biol 53: 874-878, 2008

40. Su X, Yang F and Duan X, Yuan L, Li Y and Wu L: Expression of CLC-7 during mouse tooth development. J Pract Stomatol 24 342-345, 2008. (In Chinese)

41. Duan X, Mao Y, Yang T, Wen X, Wang H, Hou J, Xue Y and Zhang R: ClC-5 regulates dentin development through TGF-beta1 pathway. Arch Oral Biol 54: 1118-1124, 2009.

42. Josephsen K, Takano Y, Frische S, Praetorius J, Nielsen S, Aoba T and Fejerskov O: Ion transporters in secretory and cyclically modulating ameloblasts: A new hypothesis for cellular control of preeruptive enamel maturation. Am J Physiol Cell Physiol 299: C1299-C1307, 2010.

43. Lacruz RS, Nanci A, White SN, Wen X, Wang H, Zalzal SF, Luong VQ, Schuetter VL, Conti PS, Kurtz I and Paine ML: The sodium bicarbonate cotransporter $(\mathrm{NBCe} 1)$ is essential for normal development of mouse dentition. J Biol Chem 285: 24432-24438, 2010

44. Okumura R, Shibukawa Y, Muramatsu T, Hashimoto S, Nakagawa K, Tazaki M and Shimono M: Sodium-calcium exchangers in rat ameloblasts. J Pharmacol Sci 112: 223-230, 2010.

45. Bronckers AL, Guo J, Zandieh-Doulabi B, Bervoets TJ, Lyaruu DM, Li X, Wangemann $\mathrm{P}$ and DenBesten $\mathrm{P}$. Developmental expression of SLC26A4 (Pendrin) during amelogenesis in developing rodent teeth. Eur J Oral Sci 119 (Suppl 1): S185-S192, 2011.

46. Hu P, Lacruz RS, Smith CE, Smith SM, Kurtz I and Paine ML: Expression of the sodium/calcium/potassium exchanger, NCKX4, in ameloblasts. Cells Tissues Organs 196: 501-509, 2012.

47. Lacruz RS, Smith CE, Moffatt P, Chang EH, Bromage TG Bringas P Jr, Nanci A, Baniwal SK, Zabner J, Welsh MJ, et al: Requirements for ion and solute transport, and $\mathrm{pH}$ regulation during enamel maturation. J Cell Physiol 227: 1776-1785, 2012.

48. Lacruz RS, Brookes SJ, Wen X, Jimenez JM, Vikman S Hu P, White SN, Lyngstadaas SP, Okamoto CT, Smith CE and Paine ML: Adaptor protein complex 2 (ap-2) mediated, clathrin dependent endocytosis, and related gene activities, are a prominent feature during maturation stage amelogenesis. J Bone Miner Res 28: 672-687, 2013.

49. Lacruz RS, Smith CE, Kurtz I, Hubbard MJ and Paine ML: New paradigms on the transport functions of maturation-stage ameloblasts. J Dent Res 92: 122-129, 2013

50. Duan X: Ion channels, channelopathies, and tooth formation. J Dent Res 93: 117-125, 2014.

51. Bronckers AL, Lyaruu D, Jalali R, Medina JF, Zandieh-Doulabi B and DenBesten PK: Ameloblast modulation and transport of $\mathrm{Cl}-$, $\mathrm{Na}+$, and $\mathrm{K}+$ during amelogenesis. J Dent Res 94: 1740-1747, 2015

52. Wright JT, Kiefer CL, Hall KI and Grubb BR: Abnormal ename development in a cystic fibrosis transgenic mouse model. J Dent Res 75: 966-973, 1996.

53. Sui W, Boyd C and Wright JT: Altered $\mathrm{pH}$ regulation during enamel development in the cystic fibrosis mouse incisor. J Dent Res 82: 388-392, 2003.

54. Bronckers AL, Kalogeraki L, Jorna HJ, Wilke M, Bervoets TJ, Lyaruu DM, Zandieh-Doulabi B, Denbesten PK and de Jonge H: The cystic fibrosis transmembrane conductance regulator (CFTR) is expressed in maturation stage ameloblasts, odontoblasts and bone cells. Bone 46: 1188-1196, 2010
55. Ko SB, Zeng W, Dorwart MR, Luo X, Kim KH, Millen L, Goto H, Naruse S, Soyombo A, Thomas PJ and Muallem S Gating of CFTR by the STAS domain of SLC26 transporters. Nat Cell Biol 6: 343-350, 2004.

56. Mount DB and Romero MF: The SLC26 gene family of multifunctional anion exchangers. Pflugers Arch 447: 710-721, 2004.

57. Ishiguro H, Steward MC, Naruse S, Ko SB, Goto H, Case RM, Kondo T and Yamamoto A: CFTR functions as a bicarbonate channel in pancreatic duct cells. J Gen Physiol 133: 315-326, 2009.

58. Shcheynikov N, Kim KH, Kim KM, Dorwart MR, Ko SB, Goto H, Naruse S, Thomas PJ and Muallem S: Dynamic control of cystic fibrosis transmembrane conductance regulator $\mathrm{Cl}(-) / \mathrm{HCO} 3(-)$ selectivity by external Cl(-). J Biol Chem 279: 21857-21865, 2004.

59. Pushkin A and Kurtz I: SLC4 base $\left(\mathrm{HCO}_{3}{ }^{-}, \mathrm{CO}_{3}{ }^{2-}\right)$ transporters: Classification function, structure, genetic diseases, and knockout models. Am J Physiol Renal Physiol 290: F580-F599, 2006.

60. Jalali R, Guo J, Zandieh-Doulabi B, Bervoets TJ, Paine ML, Boron WF, Parker MD, Bijvelds MJ, Medina JF, DenBesten PK and Bronckers AL: NBCel (SLC4A4) a potential pH regulator in enamel organ cells during enamel development in the mouse. Cell Tissue Res 358: 433-442, 2014.

61. Bronckers AL, Lyaruu DM, Jansen ID, Medina JF, Kellokumpu S, Hoeben KA, Gawenis LR, Oude-Elferink RP and Everts V: Localization and function of the anion exchanger Ae2 in developing teeth and orofacial bone in rodents. J Exp Zool B Mol Dev Evol 312B: 375-387, 2009.

62. Arquitt CK, Boyd C and Wright JT: Cystic fibrosis transmembrane regulator gene (CFTR) is associated with abnormal enamel formation. J Dent Res 81: 492-496, 1999.

63. Gawenis LR, Ledoussal C, Judd LM, Prasad V, Alper SL, Stuart-Tilley A, Woo AL, Grisham C, Sanford LP, Doetschman T, et al: Mice with a targeted disruption of the AE2 Cl-/HCO3- exchanger are achlorhydric. J Biol Chem 279: 30531-30539, 2004.

64. Dinour D, Chang MH, Satoh J, Smith BL, Angle N, Knecht A, Serban I, Holtzman EJ and Romero MF: A novel missense mutation in the sodium bicarbonate cotransporter (NBCe1/SLC4A4) causes proximal tubular acidosis and glaucoma through ion transport defects. J Biol Chem 279: 52238-52246, 2004.

65. Inatomi J,Horita H, Braverman N, Sekine T, Yamada H, Suzuki Y, Kawahara K, Moriyama N, Kudo A, Kawakami H, et al: Mutational and functional analysis of SLC4A4 in a patient with proximal renal tubular acidosis. Pflugers Arch 448: 438-444, 2004.

66. Royaux IE, Belyantseva IA, Wu T, Kachar B, Everett LA, Marcus DC and Green ED: Localization and functional studies of pendrin in the mouse inner ear provide insight about the etiology of deafness in pendred syndrome. J Assoc Res Otolaryngol 4: 394-404, 2003

67. Wall SM, Hassell KA, Royaux IE, Green ED, Chang JY, Shipley GL and Verlander JW: Localization of pendrin in mouse kidney. Am J Physiol Renal Physiol 284: F229-F241, 2003.

68. Wangemann P, Kim HM, Billings S, Nakaya K, Li X, Singh R, Sharlin DS, Forrest D, Marcus DC and Fong P: Developmental delays consistent with cochlear hypothyroidism contribute to failure to develop hearing in mice lacking Slc26a4/pendrin expression. Am J Physiol Renal Physiol 297: F1435-F1447, 2009.

69. Wang SS, Devuyst O, Courtoy PJ, Wang XT, Wang H, Wang Y, Thakker RV, Guggino S and Guggino WB: Mice lacking renal chloride channel, CLC-5, are a model for Dent's disease, a nephrolithiasis disorder associated with defective receptormediated endocytosis. Hum Mol Genet 9: 2937-2945, 2000.

70. Duan X: Spatial-temporal distribution of CLC-5 in rat tooth germ development. J Dent Res 83: 2741, 2004.

71. Guo J, Bervoets TJ, Henriksen K, Everts V and Bronckers AL: Null mutation of chloride channel 7 (Clcn7) impairs dental root formation but does not affect enamel mineralization. Cell Tissue Res 363: 361-370, 2016.

72. Leisle L, Ludwig CF, Wagner FA, Jentsch TJ and Stauber T: $\mathrm{ClC}-7$ is a slowly voltage-gated $2 \mathrm{Cl}(-) / 1 \mathrm{H}(+)$-exchanger and requires Ostm1 for transport activity. EMBO J 30: 2140-2152, 2011.

73. Lange PF, Wartosch L, Jentsch TJ and Fuhrmann JC: ClC-7 requires Ostm1 as a beta-subunit to support bone resorption and lysosomal function. Nature 440: 220-223, 2006.

74. Kornak U, Kasper D, Bösl MR, Kaiser E, Schweizer M, Schulz A, Friedrich W, Delling G and Jentsch TJ: Loss of the ClC-7 chloride channel leads to osteopetrosis in mice and man. Cell 104: 205-215, 2001 
75. Kasper D, Planells-Cases R, Fuhrmann JC, Scheel O, Zeitz O, Ruether K, Schmitt A, Poët M, Steinfeld R, Schweizer M, et al: Loss of the chloride channel ClC-7 leads to lysosomal storage disease and neurodegeneration. EMBO J 24: 1079-1091, 2005 .

76. Steinberg BE, Huynh KK, Brodovitch A, Jabs S, Stauber T, Jentsch TJ and Grinstein S: A cation counterflux supports lysosomal acidification. J Cell Biol 189: 1171-1186, 2010.

77. Wen X, Lacruz RS and Paine ML: Dental and cranial pathologies in mice lacking the $\mathrm{Cl}(-) / \mathrm{H}(+)$-exchanger $\mathrm{ClC}-7$. Anat Rec (Hoboken) 298: 1502-1508, 2015.

78. Tripp BC, Smith K and Ferry JG: Carbonic anhydrae: New insights for an ancient enzyme. J Biol Chem 276: 48615-48618, 2001.

79. Chegwidden WR and Carter ND: Introduction to the carbonic anhydrases. EXS 90: 14-28, 2000.

80. Lin HM, Nakamura H, Noda T and Ozawa H: Localization of $\mathrm{H}(+)$-ATPase and carbonic anhydrase II in ameloblasts at maturation. Calcif Tissue Int 55: 38-45, 1994.

81. Fan Y, Zhou Y, Zhou X, Sun F, Gao B, Wan M, Zhou X, Sun J, $\mathrm{Xu} \mathrm{X}$, Cheng L, et al: MicroRNA 224 regulates ion transporter expression in ameloblasts to coordinate enamel mineralization. Mol Cell Biol 35: 2875-2890, 2015.

82. Brown WE, Edelman N and Tomzaic BB: Octacalcium phosphate as precursors in biomineral formation. Adv Dent Res 1: 306-313, 1987

83. Kawase T and Suzuki A: Studies on the transmembrane migration of fluoride and its effects on proliferation of L-929 fibroblasts ( $\mathrm{L}$ cells) in vitro. Arch Oral Biol 34: 103-107, 1989.

84. He H, Ganapathy V, Isales CM and Whitford GM: pH-dependent fluoride transport in intestinal brush border membrane vesicles. Biochim Biophys Acta 1372: 244-254, 1998.
85. Mittal M and Flora SJ: Effects of individual and combined exposure to sodium arsenite and sodium fluoride on tissue oxidative stress, arsenic and fluoride levels in male mice. Chem Biol Interact 162: 128-139, 2006

86. Jin XQ, Xu H, Shi HY, Zhang JM and Zhang HQ Fluoride-induced oxidative stress of osteoblasts and protective effects of baicalein against fluoride toxicity. Biol Trace Elem Res 116: 81-89, 2007.

87. Varol E, Icli A, Aksoy F, Bas HA, Sutcu R, Ersoy IH, Varol S and Ozaydin M: Evaluation of total oxidative status and total antioxidant capacity in patients with endemic fluorosis. Toxicol Ind Health 29: 175-180, 2013

88. Sharma R, Tsuchiya M and Bartlett JD: Fluoride induces endoplasmic reticulum stress and inhibits protein synthesis and secretion. Environ Health Perspect 116: 1142-1146, 2008.

89. Kubota K, Lee DH, Tsuchiya M, Young CS, Everett ET, Martinez-Mier EA, Snead ML, Nguyen L, Urano F and Bartlett JD: Fluoride induces endoplasmic reticulum stress in ameloblasts responsible for dental enamel formation. J Biol Chem 280: 23194-23202, 2005.

90. Lyaruu DM, de Jong M, Bronckers AL and Wöltgens JH: Ultrastructure of in-vitro recovery of mineralization capacity of fluorotic enamel matrix in hamster tooth germs pre-exposed to fluoride in organ culture during the secretory phase of amelogenesis. Arch Oral Biol 32: 107-115, 1987.

91. Smith CE, Nanci A and Denbesten PK: Effects of chronic fluoride exposure on morphometric parameters defining the stages of amelogenesis and ameloblast modulation in rat incisors. Anat Rec 237: 243-258, 1993

92. Zhou R, Zaki AE and Eisenmann DR: Morphometry and autoradiography of altered rat enamel protein processing due to chronic exposure to fluoride. Arch Oral Biol 41: 739-747, 1996. 